\title{
Persistence of Folly
}




\section{signale}

modern german letters, cultures, and thought

Series editor: Peter Uwe Hohendahl, Cornell University

Signale: Modern German Letters, Cultures, and Thought publishes new English-language books in literary studies, criticism, cultural studies, and intellectual history pertaining to the German-speaking world, as well as translations of important German-language works. Signale construes "modern" in the broadest terms: the series covers topics ranging from the early modern period to the present. Signale books are published under a joint imprint of Cornell University Press and Cornell University Library in electronic and print formats. Please see http://signale.cornell.edu/. 


\title{
Persistence of Folly
}

\author{
On the Origins of \\ German Dramatic Literature
}

\author{
Joel B. LANDE
}

\begin{abstract}
A Signale Book
Cornell University Press and Cornell University Library ITHACA AND LONDON
\end{abstract}


Cornell University Press and Cornell University Library gratefully acknowledge the College of Arts \& Sciences, Cornell University, for support of the Signale series. Publication has also been made possible by the generous support of the University Committee on Research in the Humanities and Social Sciences (UCRHSS), Princeton University.

\section{Copyright $\odot 2018$ by Cornell University}

All rights reserved. Except for brief quotations in a review, this book, or parts thereof, must not be reproduced in any form without permission in writing from the publisher. For information, address Cornell University Press, Sage House, 512 East State Street, Ithaca, New York 14850.

First published 2018 by Cornell University Press and Cornell University Library

Printed in the United States of America

Library of Congress Cataloging-in-Publication Data

Names: Lande, Joel B., author.

Title: Persistence of folly : on the origins of German dramatic literature / Joel B. Lande.

Description: Ithaca, NY : Cornell University Press and Cornell University Library, 2018. I Series: Signale : modern German letters, cultures, and thought I Includes bibliographical references and index. Identifiers: LCCN 2018021945 (print) | LCCN 2018022513 (ebook) | ISBN 9781501727139 (epub/mobi) | ISBN 9781501727122 (pdf) | ISBN 9781501727108 I ISBN 9781501727108 (cloth ; alk. paper) | ISBN 9781501727115 (pbk. ; alk. paper)

Subjects: LCSH: German drama-Early modern, 1500-1700—History and criticism. I German drama-18th century-History and criticism. I Fools and jesters in literature. I German drama (Comedy) - History and criticism.

Classification: LCC PT638 (ebook) I LCC PT638 .L36 2018 (print) | DDC 832/.009-dc23

LC record available at https://lccn.loc.gov/2018021945 
Geschäftige Torheit ist der Charakter unserer Gattung.

Busied folly is the character of our kind.

-Immanuel Kant, Contest of the Faculties 
